\title{
Bir İnşaa Süreci Olarak Erkeklik: Yozgat Örneği ${ }^{1}$
}

$* * *$

\section{Masculinity As a Construction Process: The Case of Yozgat ${ }^{1}$}

\author{
Dr. Öğr. Üyesi Esra Gedik \\ Yozgat Bozok Üniversitesi, FEF, esra.gedik@bozok.edu.tr \\ ORCID: 0000-0000-0000-0000 \\ Dr. Öğr. Üyesi Hülya Çakır \\ Yozgat Bozok Üniversitesi, FEF, hulya.cakir@bozok.edu.tr \\ ORCID: 0000-0001-8115-4076
}

Anıl Çoşkun

Yozgat Bozok Üniversitesi, FEF, anilcoskun52@hotmail.com ORCID: 0000-0002-1645-4686

\begin{abstract}
Özet
Türkiye alan yazınına baktığımızda, erkeklik çalışmaları ve erkeklik incelemeleri, hakkında konuşulan ama akademik olarak hakkında çok fazla çalışma yapılmamış konular olarak karşımıza çıkar. Uluslararası alan yazında erkeklik çalışmaları 1970'li yıllarda tartışılmaya başlansa da Türkiye'de üzerine çalışmalar yapılması 2000'li yılları bulmaktadır. İlgili literatürü incelediğimizde, toplum içerisinde değişen söylemlere göre şekillenen farklı erkeklik kültürleri olduğu görülür. $\mathrm{Bu}$ minvalde, erkeklikten değil erkekliklerden bahsedilir. Toplumların farklı sosyoekonomik ve kültürel yapılarına göre farklı erkeklikler ortaya çıkar. Aynı toplum içinde bile bölgelerin farklı kültürel yapılarına göre farklı erkeklik modellerinden bahsedilebilir. Buna rağmen aynı toplum içerisinde diğer erkekliklerin kendini ona göre kurguladığı hegemonik erkeklik unsurlarından söz edilebilir. Türkiye'deki erkeklik incelendiğinde geleneksel bir hegemonik erkeklik algısı olmasına rağmen "Trabzon erkekliği, İstanbul erkekliği vb." gibi farklı erkeklik söylemleri karşımıza çıkar. Bu anlamda bu çalışmada Yozgat'ta erkeklik incelemesi yapılmıştır. Yozgat'ta yaşayan 20- 65 yaş arası 25 erkekle ile yapılandırılmış açık uçlu görüşmeler yapılmıştır. Bu görüşmeler sonucunda Yozgat'ta erkeklik kültürel unsurlar taşısa da Türkiye'de var olan hegemonik erkeklik anlayışını sünnet, askerlik, iş bulma ve evlilik pratikleri üzerinden yeniden üretmektedir.
\end{abstract}

Anahtar Kelimeler: Erkeklik, Hegemonik Erkeklik, Yozgat, Toplumsal Cinsiyet.

Abstract
In Turkey, masculinity studies and masculinity reviews left barely studied in the academic literature although have
been frequently talked about. Discussions on masculinity studies commenced in 1970s in the international literature
but it was not until 2000s that the topic became a research subject in Turkey. Examination of the relevant literature
reveals the existence of different masculinity cultures which take shape depending on the discourses within the society.
In this regard, it is masculinities not the masculinity that has been addressed. Different forms of masculinities emerge
from different socioeconomic and cultural structures of societies. Even within the same society, cultural structures
that vary by region result in different models of masculinity. Nevertheless, there are elements of hegemonic
masculinity prevalent in each society, based on which other masculinities within the same society are constructed. In
Turkey, despite the presence of a traditional perception of hegemonic masculinity, we can still observe different
discourses such as Trabzon masculinity, Istanbul masculinity, and so on. This study examines masculinity in Yozgat,
in which structured open-ended interviews were made with 25 men aged 20-65 who live in Yozgat. Based on the
interviews, it can be said that although masculinity in Yozgat has some cultural elements to it, it reproduces the

\footnotetext{
${ }^{1}$ Lisans bitirme tezinden üretilmiştir.

${ }^{1}$ It is derived from the undergraduate thesis.
} 
understanding of hegemonic masculinity through the practices of circumcision, military service, finding a job and marriage.

Keywords: Masculinity, Hegemonic Masculinity, Yozgat, Gender.

\section{GİRIŞ̧}

Toplumsal cinsiyet çalışan araştırmacılar (Ecevit ve Karkıner, 2011; Bora, 2012; Beşpınar, 2014; Sancar, 2014; Oakley, 2015; vb.) uzun süredir erkek egemen toplumlarda ve sistemlerde erkeğin yüceltilmesinin kadınlar açısından yarattığı sonuçları, ayrımcılıkları ve eşitsizlikleri tartışıyorlar. Öte yandan, eril sistemin erkekler açısından ne ifade ettiği ve bunun, erkeklerin hayatlarını nasıl kurduğu tartışmaları nispeten yeni başlayan tartışmalardır (Gedik, 2016). Günümüzde erkeklik kavramı, toplumsal cinsiyet odaklı çalışmaların önde gelen konu başlıklarındandır. Erkeklik ile ilgili tartışmaların cevabını aradığı ilk sorulardan biri “erkekliğin ne olduğu ve nasıl tanımlanabileceğidir” (Sancar, 2008: 31).

Toplumsal cinsiyet rolleri geçmişten günümüze sürekli tartış1lan bir konu olmuştur. Birey, doğumundan itibaren çevresinden gördüğü ve edindiği bilgileri öğrenerek toplum içine karışır ve böylelikle toplumda kendine yer edinmeye çalışır. Toplum içinde biyolojik yapılarına, kadın ve erkek oluşlarına bağlı olarak kimlik inşa edilir. Başka bir deyişle, toplumun bireye atfettiği biyolojik cinsiyeti üzerinden kurgulanan toplumsal kadınlık ve erkeklik rollerine göre içerisinde yaşadığı toplumun toplumsal cinsiyet rejimine göre bir kimlik edinir. Birey doğduğu andan itibaren toplumun biyolojisine yüklediği sosyo-kültürel anlamlara bağlı olarak toplum içinde sosyalleşerek toplumsal cinsiyet kimliğini geliştirir. Toplumsal cinsiyet rolleri ile insanlar toplumda kabul edilen kadınlık ve erkeklik algılarını benimserler. Connell (1995) ise, erkekliği bir toplumsal cinsiyet düzeni olarak tanımlar; öyle ki bu toplumsal düzende erkeklerin iktidarı hüküm sürmektedir. Sancar'a göre ise erkeklik "iktidar inşasıdır” (Sancar, 2009: 19). Erkekten beklenen roller yerine getirmesi gereken kurallar haline gelmiştir. Erkek toplum tarafından beklenenleri yerine getirdiği zaman "güçlü” olarak görülmüş ve toplum tarafından "değer" verilen bir birey olmuştur; fakat erkek toplum beklentilerini (toplumsal cinsiyet rollerini, görevlerini) toplumun atfettirdiklerini yerine getirmediği zaman dışlanma ile karşılaşmıştır. Çünkü toplum içerisinde, toplum tarafından kabul edilen ve baskın olan bir erkeklik anlayışı vardır. Connell bu erkeklik anlayışını hegemonik erkeklik olarak tanımlar. Başka bir deyişle, hegemonik erkeklik bir idealdir. Sığın ve Canatan (2018) bu durumu şöyle ifade ederler, hegemonik erkeklik algısı toplumsal kurumlar aracılığı ile öğretilen bir durumdur. Ailede, okulda, medya aracılığı ile toplumda sürekli yeniden üretilir. Örneğin, "Erkekler ağlamaz!”, "Erkek dediğin dayanıklı olur!” gibi. Bu algılar öyle bir baskı yaratır ki sanki başka erkeklikler olamazmış gibi.

Her toplumun erkekliğe bakış açısı beklentisi farklıdır. Bu kalıp yargılar (erkek adam ağlamaz, erkek evin reisidir, erkek dediğin güçlü olur, vb.) erkek kavramının algılanışını ve değerlendirilişini oluşturur. Bu farklılaşmayı ataerkil toplumun değerleri, beklentileri belirler. Kadın ve erkek olmak, kültürün ve toplumun getirdiği anlam ve beklentilerdir. Bu beklentiler kadınla erkek kimlikleri belirlenmiş olur. Bireyler, toplumun kendilerinden kadın ya da erkek olarak ne beklediğini öğrenmiş olurlar. Bireyler toplumun beklentilerini her zaman karşılayamayabilir fakat bireyler bu beklentileri karşılayamasalar da bu beklentilerden sorumlu olacaklarını öğrenirler. Örneğin, pek çok toplumda pembe kadın rengi olarak kabul edilir. Bu durumda, liseye giden genç bir erkeğin pembe gömlekle okula gelmesi var olan erkeklik kurgusuna ters düşer. Diğer erkek arkadaşları pembe giyen genç erkekle "yarım, nonoş, ibne" şeklinde dalga geçebilirler. $\mathrm{Bu}$ şekilde toplumda erkekler, diğer erkeklere ve kadınlara kabul edilen erkeklik anlayışını ve bu erkeklikten neler beklediklerini bu ve benzeri pratiklerle öğretirler. Hâsılı toplum tarafından ne kadar bu kimliğe uygun oldukları bireyler kendileri de toplum tarafından da değerlendirirler. Örneğin, toplumsal cinsiyete dayalı iş bölümüne göre erkekler hane içinde ev işlerinden sorumlu tutulmazlar. Bu nedenle, çoğu zaman, Türkiye'de evde kadınlara yardım eden erkeklere, diğer erkekler "kılıbık, hanımköylü” gibi yaftalamalarla beklenen erkekliğe uymadıklarını gösterirler. 
Hem kadınlar hem de erkekler toplumun uygun gördüğü toplumsal cinsiyet rollerini benimsemeye çalışırlar. Örneğin Türkiye'de küçük yaşlardan itibaren kadınlara yemek pişirmek ve temizlik yapmak gibi ev ile ilgili beceriler, erkeklere ise araba kullanmak ve tamir etmek gibi ekonomik anlamda kullanabilecekleri beceriler yüklenmektedir. Bu toplumsal rol dağılımı bireyler arası ilişkilerde desteklenerek devamlılık kazanmaktadır. Toplumsal cinsiyete dayalı rol dağılımı çocukluğun ilk dönemlerinde başlar ve yaşamın sonraki dönemlerinde devam eder. Bu roller en yoğun şekilde yetişkinlik döneminde oluşturulur. Örneğin, kadınların sevecenlik duygusundan öğretmen, hemşire ve doktor gibi meslekler ve aynı zamanda ev işleri, çocuk bakımıyla ilgilenmeleri beklenirken; erkeklerin ekonomik kaynak sağlama ve fiziksel güçlerini kullanacakları alanlarla ilgilenmeleri beklenir. Çakır'a göre “toplumsal cinsiyetçi yapı içerisinde erkeklerin yaşamları güce sahip olmak, güç üretmek ve gücün kendisi olmak biçiminde inşa edilmiştir. Güç, erkeklerin yalnızca kadın ve çocuklar üzerinde değil, aynı zamanda birbirlerine karşı da geliştirdikleri bir olgudur" (Çakır, 2017: 322). Türkiye'de erkeklik belirli kademeleri geçmekle mümkündür. Tek bir erkeklik tipi yoktur fakat toplumda egemen olan genel geçer olarak kabul edilen bir hegemonik erkeklik vardır. "Erkeklikler" aynı toplumda bile olsa farklı gruplar tarafindan farklı şekillerde yorumlanabilir (Kimmel, 2004: 503). Burada önemli olan erkeklik ve erkek kavramlarının birbirinden farklı olmasının göz ardı edilmemesidir. Erkeklik, bir cinsiyete ait olmanın ötesinde bir iktidar biçimidir. "Erkek olabilmek" için bireyin neler yapması gerektiği toplum tarafından belirlenmiştir. Türkiye özelinde erkeklik unsurlarının nasıl kurgulandığına ve bir oğlan çocuğunun "erkek olmak" için hangi aşamalardan geçtiğine bakmak yararlı olacaktır: Sünnet, askerlik, iş bulma ve evlilik. Bu çalışma özelinde ise Yozgat'ta erkek bireylerin erkekliklerini nasıl kurduklarını ve erkek olmak için hangi süreçlerden geçtiği araştırılmıştır.

Kentin merkezi ve merkez ilçelerindeki istatistikler bize gösteriyor ki Yozgat; şehir merkezinde erkeklerin yoğun olduğu bir şehirdir (Yozgat Nüfusu, 2019). Türkiye'de ataerkillikle şekillenen güçlü bir "erkeklik" söz konusudur. Pek çok şehrin kendine has bir erkeklik algısı bulunmaktadır. Örneğin, Trabzon erkekliği (Bozok, 2013). Bu çalışmada, Türkiye'deki erkeklik çalışmalarında pek yer almayan, bölgesel erkeklik çalışmaları açısından Yozgat'ta erkekliğin nasıl yaşandığı araştırıldı. Bir yandan Türkiye'deki, hegemonik erkeklikle kesişen yanları, öte yandan da Yozgat'a özgü kültürel ve toplumsal özellikleri de taşııp taşımadığı incelenmiştir. Yozgat'ın milliyetçi, muhafazakâr sosyo-kültürel yapısının Trabzon erkekliği algısında olduğu gibi bir Yozgat erkekliği yaratıp yaratmadığı incelenmiştir. Bu çalışmamın amacı değişen toplumsal yapıların, toplumsal cinsiyet rollerini etkilemesiyle geleneksel erkek modelinin değerlerinin ve kimlik inşa süreçlerindeki deneyimlerini ve sıkıntılarını araştırmaktır. Toplumsal cinsiyetin erkeklik kalıpları ve toplumun erkek bireyden beklentileri Yozgat ili örneğinde sorgulanmak istenmektedir. Bu araştırmanın amac1, Yozgat'ta erkekliğin nasıl kurulduğunu ve bu aşamalarda hegemonik erkekliğin nasıl bir anlam taşıdığını araştırmaktır.

\section{Bir İnşa Süreci Olarak Erkeklik}

Biyolojik olarak erkek olarak doğmak, insanları erkek yapmaz (MacInnes, 1998: 15). Erkeklik toplumsal ilişkiler yoluyla kolektif olarak inşa edilen, bir sürecin ürünü olarak her daim değişime açık olan bir toplumsal cinsiyet kimliğidir. Erkeklik inşası, bir erkeğin çocukluğundan itibaren başlayıp, hayatının sonuna kadar devam eden bir süreç olarak karşımıza çıkmaktadır. "Bir toplumsal inşa olarak erkeklik çokludur; bir kültürden diğerine ve zaman içinde (hatta bir erkeğin hayatı boyunca) değişmektedir" (Hacısoftaoğlu ve Bulgu, 2015: 114). "Erkek olma" zorunluluğu bulunan erkek birey, hangi durumlarda nasıl bir tavır takınması gerektiğini öğrenmiş olmalıdır. Erkeklik inşası nasıl gerçekleşmektedir? Türkiye'de erkeklik nasıl inşa edilmekte ve nasıl içselleştirilmektedir?

Connell (2000), tek bir erkeklik modeli olmadığını, "erkeklik” (masculinity) hakkında değil, "erkeklikler" (masculinities) hakkında konuşmamız gerektiğini vurgular. Başka bir deyişle, farklı kültürlerin farklı erkeklikler kurguladığını ifade eder. Kültürel değerler ve geleneksel roller ve normlar erkeklik algısını 
şekillendirir. 1970'lerde başlayan erkeklik çalışmaları 1980'li yıllardan itibaren daha derinlikli işlenmeye başlanmıştır. Renkmen (2012: 17) çalışmasında 1970'li yıllarda etkin olan tek bir katı yapı olarak var olan erkek algısı olduğunu, başka bir deyişle, evrensel, doğal, ezeli ve ebedi bir erkelik algısının yaygın olduğunu dile getirir. 1980'li yıllarda "farklı erkeklik" deneyimlerinin olup olmadığı araştırılmaya başlanmış ve tek tip erkeklik tanımına karşı eleştirel bir bakış açısı gelişmeye başlamıştır (Sancar, 2011; Bozok, 2011; Renkmen, 2012). Kepekçi şöyle ifade eder: "Erkeklikler aynı toplum ve zamanda bile olsa farklı grup, söylem ve ideolojiler tarafından farklı şekilde tanımlanabilir.” (Kepekçi, 2012: 62). Hegemonik erkeklik durağan değildir, bu nedenle eski biçimlerle yeni biçimler, sürekli yer değiştirir (Connell ve Messerschmidt, 2005). Gedik (2016: 42) bu durumu şöyle yorumlar "Bu açıdan, sabit, değişmez bir erkek tanımlaması yapılamaz. Bu nedenle evrensel bir erkeklikten değil ancak farklı erkeklik deneyimlerinden yani "erkekliklerden" söz edilebilir." Pek çok farklı erkeklikten ve erkekliklerden bahsedilebilir olmasının yanında, topluma egemen olmuş tek bir hegemonik erkeklik ${ }^{2}$ algısından da bahsedebiliriz. Hegemonik erkeklik kavramı toplumda baskın ve yaygın olan erkeklik anlayışı olarak yorumlanabilir. Hegemonik erkeklik bir toplum tarafından idealize edilmiş erkeklik biçimidir ve toplumda var olan diğer erkeklik rollerinin kendilerini bu erkeklik tipine göre konumlandırmasını ister, ayrıca kadınların toplumda ikincil konumunu da meşrulaştırmaktadır.

Türkiye'de erkekliğin sosyalizasyon sürecini ve tahakküm ilişkilerini çözümlemeye yönelik çalışmalar, sünnet törenleri, askerlik, iş bulma ve evlilik gibi aşamaları mercek altına almıştır (Selek, 2008; Sancar, 2009). Türkiye'de geleneksel olarak kabul gören erkeklik kademesine varmak için yukarıda sayılan aşamaları geçmek gerekmektedir. Örneğin, Türkiye'de güçlü, asker, milliyetçi ve savaşçı olmak hegemonik erkeklik rolünün önemli parçasıdır. "Her Türk asker doğar" gibi sözlerle olması gereken erkeklik, hegemonik erkeklik tanımlanır ve bu ideale uymayan erkeklerin, örneğin askerlik yap(a)mayan erkeklerin erkekliği sorgulanır, dışlanır, karikatürize hale getirilir. Buna ek olarak, Türkoğlu (2013) durumu şöyle ifade eder "askerliğin erkeklik inşası üzerindeki etkisi erkekliğin yeniden üretimindeki en temel unsurlardandır.” Öztürk’e (2013) göre "bir kültürü niteleyen alışkanlıklar seti, davranış biçimleri, inançlar ve gelenekler, aynı zamanda bedene de göndermede bulunmaktadır." Bu anlamda, sünnet Türkiye'de erkeklik için önemli bir bedensel ritüeldir. Barutçu'ya (2013) göre "sünnet, Türkiye'de erkek çocuklarının aşması gereken ilk ciddi bedensel aşama olarak algılanmaktadır." Bir diğer unsur da erkeklerin aile reisi olmaları ve çalışıyor olmasıdır (Sancar, 2009).

Tüm bunların dışında erkeklik kırılgan bir yapıya sahiptir. Hâsılı sürekli ispatlanması ve savunulması gerekir. "Yeterince erkek olmak" diğer erkek grupları arasında kabul görmek ile ilgilidir. Bu nedenle de erkekliğin kabul edilmesi ve onaylanması için homososyal ${ }^{3}$ ilişkiler önemli rol oynar. Erkekler doğdukları andan itibaren içinde bulundukları cinsel kimliğin nasıl olması gerektiği doğrultusunda homososyal bağlar aracılığı bilgi edinirler. Örneğin, "Erkekler, bir araya geldiklerinde kendi cinsleri dışındakilere ilişkin aşağılayıcı espriler ve konuşmalarla erkekliklerini homojenleştirirler. Bu aynı zamanda erkekler üzerinde kayg1 ve bask1 da yaratan bir durumdur." (Cengiz, Tol ve Küçükural, 2004). Sancar'ın (2009) "erkek ortaklıklarını anlamak için homososyal erkek mekânlarının 'habitus'unu, erkek eğlence dünyasının eril tarzını, spor salonlarındaki 'erkeklik inşası'nı, iş görüşmelerindeki erkek-erkeğe halleri anlamak önemlidir” şeklindeki tespiti Yozgat’taki erkek erkeğe ilişkileri yorumlamak açısından da önemlidir. Ülkemizde sünnet ile başlayan bu inşaa süreci: ilk cinsel deneyim, askerlik, çalışma hayatı, evlilik, babalık vb. gibi alanlarla

\footnotetext{
${ }^{1}$ Metin içerisinde erkeklik kavramsal anlamda kullanılırken erkeklikler bu kavramın yarattığ farklı erkeklik deneyimlerini tanımlamak için kullanılmıştır.

${ }^{2}$ Connell ve Messerschmidt (2005), hegemonik erkeklik tanımı yanında "suç ortağı erkeklik","madun erkeklik" ve "marjinal erkeklik" tanımlaması da yapar.

${ }^{3}$ Homososyallik kavramı aynı cinsiyetteki kişiler arasındaki sosyal bağları tanımlar. Kavram, erkekler ve erkeklikler üzerine yapılan çalışmalarda sık sık kullanılmaya başlanmış, erkek dostluğu, erkek bağları ve kardeşlik kodları üzerine yapılan çalışmalarda karşımıza çıkmaktadır (Bird 1996; Flood, 2008; Gedik, 2018). Gedik (2018, s.63) kavramı şöyle tanımlamaktadır "Homososyallik, erkeklerin kendilerini ataerkil bir cinsiyet düzeninde diğer erkeklere yönelttikleri uygulamalar olarak anlaşılmaktadır".
} 
sürekli olarak sınanır. Bu nedenle ilerleyen bölümde, alan araştırmasından verilerle, bahsi geçen süreçlerin Yozgat'ta nasıl yaşandığı analiz edilmiştir.

\section{Araştırma Yöntemi}

$\mathrm{Bu}$ çalışmada derinlemesine görüşme veri toplama tekniği kullanılmıştır. Araştırmada Yozgat Merkez'de yaşayan 20-65 yaş arası 20 kişi ile yapılandırılmış açık uçlu görüşmeler yapılmıştır. Bilgilendirilmiş rıza onayı alındıktan sonra başlayan sohbetler ile ilgili, görüşmecilerin onayı ile notlar alınmıştır. Daha sonra bu notlar, saha notları olarak analizde kullanılmıştır. Açık uçlu yarı yapılandırılmış sorulara geçildiğinde görüşmecilerin onayı ile ses kaydı kullanılmıştır. 40 dakika ile 90 dakika arasında değişen ses kayıtları deşifre edilmiştir. Yukarıda bahsi geçen erkeklik aşamaları, alt başlıklar olmak sureti ile veriler sistematik olarak sınıflandırılmış ve konuyu en iyi yansıttığı düşünülen kayıtlardan alıntılar metinde kullanılmıştır. Görüşmecilerin kimliğini saklamak adına görüşmecilere alfabetik isimlendirme yapılmıştır. Araştırmanın evreni Yozgat İli Merkez'inde bulunan erkeklerdir. Araştırmanın örneklemi ise kartopu yöntemi ile seçilen en büyüğü 65, en küçüğü 20 yaşlarında olan 25 erkek katılımcıdan oluşmaktadır. 2018-2019 yılları arasında görüşmeler tamamlanmıştır. Erkekliğe bakış açılarını analiz edebilmek için farklı yaş gruplarına ait bireyler seçilmiştir.

\section{Yozgat'taki Erkeklik Tartışmaları}

$\mathrm{Bu}$ araştırma kapsamında erkeklere erkek olduklarını ilk ne zaman hissettikleri üzerine sorular sorulmuştur. Verilen cevaplar daha çok kadınlar ve kadın bedeni üzerine kurulu olmuştur.

“Karşı cins ile muhabbetler başladığında erkek olduğumu hissettim.” (E, 47, Esnaf)

“Çocukluğumda erkek ve kadınların aynı özelliklere sahip olduğunu düşünürdüm. Ergenlik dönemine girmemle birlikte kadın ve erkeğin farklı biyolojik özelliklere sahip oldukların anladım. Kadınların vücutlarındaki farkl yapılarını hissettiğim an erkek olduğumu hissettim." (Ş, 45, Şirket Sahibi)

"Yaşım ilerlemeye başladı̆̆ında kadınlara karşı meraklarım giderek artmaya başladı. Bununla birlikte bir abim vasitasıyla kadınlarla tanışabileceğim bir mekâna gittim. Kendimi o zaman ilk olarak erkek olarak hissettim." (K, 56, Kahveci)

Deneyimlerimiz, içinde yer aldığımız toplumsal bağlama göre sosyo-kültürel olarak yapılandırılır. Burada geleneksel erkek yapısı içerisinde kadını, bir cinsel obje olarak görme ve algılama eğilimi olduğu anlaşılmıştır. Aylin (2015) kadın bedeninin toplumdaki işlevlerini şöyle sıralamıştır: erkeğin cinsel partneri olmak, erkeğin soyunun devamını sağlama işlevi görmek, çocuğu besleme-büyütme-bakım işlevlerini sağlamak. Ataerkil söylem, bir toplumda sadece kadın bedenini ve cinselliğini değil, aynı zamanda erkek bedenini ve cinselliğini de şekillendirir (Odabaş, 2013). Yozgat'ta da Türkiye'de var olan hegemonik erkeklik değerlerinin etkin olduğu görülmektedir. Erkek olmanın heteroseksüel cinsellik anlayışından geçtiği ve kadın bedeni üzerinden bireylerin "erkek”leştiği görülmektedir.

Bununla birlikte Yozgat ilinde sorulan "yetiştiriliş sürecinde ailenizin size erkek olmanız konusunda öğrettiği şeyler nelerdir?” sorusuna toplumsal cinsiyet bağlamında toplumda kabul edilen roller çerçevesinde cevaplar verilmiştir.

"Hep babam kendi gibi birisi olmamı isteyerek yetiştirdi. Okulda bir çocukla kavga ederek eve gelmiştim. Babam evde ağladı̆̆ımı gördüğ̈̈nde "erkek adam ă̆lamaz" diyerek ilk tokatımı yemiştim. Bununla birlikte çok ă̆ladım ve erkeklerin ă̆lamaması gerektiğini öğrendim.” (S, 51, Emekli Subay)

"Biz bir klz iki erkek kardeşiz. Babam bize oyuncak aldl̆̆g zaman kız kardeşim ve benim oyuncaklarım hep farklı olurdu. Babam kı kardeşime bebek alırken bana kamyon, silah, araba 
gibi oyuncaklar alırdl. Kardeşimin bebeğini elimde gördü̈̆̈̈ zaman "erkek adam bebekle oynamaz" derdi." (M, 47, Kurum Müdürü)

Toplumsal yapı içerisinde erkek ve kadına yüklenen görevler ve sorumluluklar hep farklı olmuştur. Bunlar renkler, oyuncaklar, iş olanakları olmak üzere her alanda farklılık göstermiştir. Erkek için cesur, korkmayan, ağlamayan gibi özellikler sıralanırken; kadınlardan daha narin, zarif olmaları istenmiştir. Çelik (2016:2) araştırmasında da ortaya koyduğu gibi

"Erkekler ağlamaz!" gibi söylemlerle oluşturulan ve pekiştirilen bu süreçte erkekler, daha güçlü, daha başarılı, daha cesur olma telkinleriyle hem şiddete maruz kalmakta hem de şiddet uygulamaktadır. Şiddet döngüsüne "bunu yaparsam bana gülerler", "böyle davranırsam beni gruba dâhil etmezler" örnekleriyle çoğaltılabilecek korku ve kaygılarını bastırma yolu olarak girebilmektedirler.

Erkek toplumun yüklediği bu görev ve sorumluluklar kapsamında kendini şekillendirmiştir. Aile içerisindeki toplumsal cinsiyete dayalı iş bölümünün etkilerine erkek algısında da rastlamak mümkün.

"Erkek aşırı kıskanç ve her istediğini yapandır. Temiz, düzenli, işine gücüne bakan, sağa sola sataşmayan, hayatla mücadele verendir." (Ö, 24, Öğrenci)

"Evine ekmek getiren, ailesini koruyan, kollayan, sahip çıkan kişidir.” (F, 25, Esnaf)

Çelik'in (2016:4) çalışmasında da belirttiği gibi erkeklik homososyal bağlar ile şekillenen, aktarılan ve yeniden üretilen bir süreçtir: "erkek, hangi durumlarda nasıl bir tavır takınması gerektiğini öğrenmiş olarak yaşamına devam eder." Üniversite öğrencileri ile yapılan görüşmeler dışında, saha notları bize gösteriyor ki Ülkü Ocakları ve teşkilat yapılanması erkekler arasında yaygın ziyaret edilen yapılardır. Erkeklerin çoğu için kendilerine dost edinmeye gittikleri sosyalleşme yerleridir ama bir sebebi olmadan "birileri gidiyor dedi” diye giden erkeklerin de olduğu belirtiliyor. Bu anlamda, Ülkü Ocakları ve teşkilatlar Yozgat'taki erkeklik anlayışının oluşturulmasında katkısı olan homososyal mekânlar olarak karşımıza çıkmaktadır. Buradaki eylem, sohbet, tartışma gibi faaliyetler sırasında erkek erkeğe ilişkilerde erkek olmayı ve erkekçe konuşmayı deneyimliyorlar. Bu da bize toplum içerisinde farklı kültürel unsurların erkeklik deneyiminin şekillenmesinde ve erkeklikler oluşturulmasında etkin olduğunu gösterse de yine de Yozgat erkekliği vardır denilmesi yanlış olur. Çünkü görüşmecilerin anlatılarından da anlaşlacağı gibi Yozgat’taki erkeklik anlayışı Türkiye'deki hakim hegemonik anlayışından etkilenmektedir.

Erkek çocuklarının aile içerisinde diğer erkeklerle ilişkileri kapsamında "erkek olma"yı öğrendikleri yukarıdaki örneklerde de görülmektedir. Çocuk ilk olarak aile içerisinde şekillenen bir varlıktır. Çocuklara küçük yaşlarda erkeklik (kadınlarda da olduğu gibi) rol ve sorumluluklarının öğretilmesi onları şekillendirmiştir. Bunlar kapsamında erkeklik algısı için ailenin ve ebeveynlerin ne kadar önemli bir yapıya sahip oldukları anlaşılmıştır. Babayla özdeşleşme, erkek çocukların kimlik gelişiminde hayati bir önem taşımaktadır. Babadan, gücü, rekabeti, iktidarı, macerayı, "erkek olmayı" ve "erkek gibi davranmayı" öğrenirler. Aynı şekilde Yozgat'ın erkeklik kimliğini de yine ailedeki erkeklerle beraber kurduklanı homososyal bağlar ile öğrendikleri görülmektedir.

\subsection{Bedensel Bir Ritüel Olarak Sünnet ve Erkeklik}

Türkiye'nin çoğunluğu Müslümanlardan oluşur. Bu nedenle dini yapının gereğini yerine getirmek için erkekler sünnet olmaktadır. Sünnet olmak Türkiye'de çoğu erkek için aynı nedenlere bağlı olarak gerçekleşmiştir. Dini sebeplerle sünnet olunmasına karşın, sünnetin Atilla Barutçu tezinde Türkiye'de bir erkeğin, erkek olarak kabul edilebilmesi için çeşitli bedensel süreçlerden geçmesi gerektiğini dile getirir (Barutçu 2013:7). Sünnet de bunlardan biridir. Sünnet'in Türkiye'de erkek olma ile bağlantısı vardır. Sünnet olmak oğlan çocuğundan “erkek adam” yaratma anlamına sahiptir. Buna rağmen, Türk kültüründe erkek çocukların sünnet olma yaşı çeşitlilik göstermektedir. 
"Sünnet olduğum zaman ergenliğe erişmiştim. Biraz sünneti geç oldum yani büyük korku yaşadım. Büyük yaşta sünnet olduğun için bu durumun etkisinden kolayca çıkamadım. Geç olduğum için sıklıkla dalga geçtiler, erkek olamadın sen gibisinden.” (M, 47, Kurum Müdürü)

Sünnet de askerlik gibi "hem erkeğin kendi erkekliğini ispat etmesine, hem de başkalarının gözünde erkekliğin ifade edilmesine hizmet eder" (Onur ve Koyuncu, 2004: 40) Bu anlatı da gördüğümüz gibi erkeklik kaybedilme korkusu olan bir kurgudur. Bu nedenle belli ritüellerle ispatlanması gerekir, örneğin, cinsellik ve sünnet gibi. Bu görüşmeci bu açıdan incelendiğinde çiftte travma yaşamıştır. Hem sünnet olmadığı için erkekliğini ispat edememiş hem de geç olduğu için cinsel gücü kaybedeceği korkusunu yaşamıştır. Başka açıdan bakarsak, hegemonik erkeklik sadece kadınlar üzerinde tahakküm kurmaz "öteki" erkekler üzerinde de baskı yaratır diyebiliriz.

\section{“Erkek oluyorsun işte. Davullu zurnalı kutlanacak daha mühim başka ne var?” (B, 46, Kasap)}

Sünnet daha çok dini emirlerini yerine getirmek için yapıldığı aksettirilirken çoğunun nedeni ise toplumsal yapı içerisinde dışlanmaktan kaçınmak için olmuştur. Bunun için "sünnet düğünleri" düzenlenerek topluma, oğlan çocuklarının erkekliğe adım attıkları gösterilmek istenmiştir. Sünnet olunca, "adam olacaksın delikanlı olacaksın" derler. Bu sebeple, sünnet olmakla erkek olmak Türk toplumunda birbirinden ayrılmaz iki parça haline gelmiştir. Sünnet olmak ile erkeklik birbirine ilişkilendirilmiştir.

"Dinimizin gerektirdiği vecibe peygamberimizin sünneti olduğu için sünnet oluruz. Hem erkekliğe atılan ilk adım değil mi?" (T, 52, Terzi)

"Geçmişten gelen örf ve adetler çocuklara bunlar hissettiriliyor ve bunlar da bizde erkeklik duygusunu sünnetle iliş̧kilendirmemize yol açıyor.” (R, 53, Belediyeden Emekli).

“Sünnet olmak peygamber efendimizden gelen bir şey. Böyle erkek oluyoruz.” (Ç, 48, Çiftçi)

Sünnetin erkeklikle alakası herkes tarafından "erkekliğe adım atmak için bunun yapılması gerektiği” düşüncesi aş1lanır. Adeta bir şölen havasında düzenlenen sünnet dügünleri sayesinde biyolojik olarak erkek olan insan çocukları toplumsal olarak da erkekliğe ilk adımını atar. Erkek çocuklarının sünnete ikna edilme aşamalarına baktığımızda dinsel, kültürel ya da tıbbi sebeplerden ziyade, sünnetin çocuklara "erkek cemaatine giriş bileti” (Yavuz, 2014: 115) olarak sunulmasında yatar. Katılımcıların çoğu bu görüşü doğrulamıştır.

Erkeklik toplumsal onayı gerektiren bir durumdur. Toplumsal açıdan onay alabilmesi için topluma özgü ritüellerin yerine getirilmesi beklenir. $\mathrm{Bu}$ ritüeller bazı zamanlarda fiziksel acılara katlanma yetisi gerektirebilir. Kaldı ki Türkiye'de erkekliğin kuruluşuna baktığımızda “erkek adam ağlamaz” algısı yaygın olduğundan fiziksel acılara katlanabilmek, ağlamamak erkek olmanın şartlarından sayılmaktadır. Sünnet de böyle bir ritüeldir. Türkiye'deki erkeklik ritüellerinden olan sünnet erkeklerin yetişkinliğe geçiş için zorunlu tutulduğu, erkek egemen topluluklar aracıllğıyla kontrol edilen ve statü simgesi haline gelerek, toplumda kadın ve erkek arasındaki farklılaşmaları şekillendiren ritüllerdendir.

\subsection{Askerlik ve Erkeklik}

Askerlik Türk kültürünün içine sindirilmiştir. Askerlik erkeklikteki ikinci aşama olarak kabul edilmiştir. Vatan millet sevgisinin yanında askerliğin erkeği disipline edici rolü, olgunlaştırması toplum tarafından önem arz eder. Türkiye'de askerlik bir erkek için dönüm noktası hayatının en önemli dönemlerinden biridir. Türkiye'de işini ve ailesini kurma aşamasında olan bir erkek için askerlik zorunluluktur, vereceği kararların önünde engel niteliği teşkil eder. Diğer taraftan askerlik erkek bireyin "olgunlaşması" için zorunlu ve kaçınılmaz bir aşama olarak kabul edilir. Askerliğini yapmamış erkek "çürük" erkek olarak kabul edilir. Bunun için “Askerlik yaparken karşılaştığınız ne gibi zorluklar olmuştur?” sorusu sorulmuştur. 
"Benim için hiçbir zorluğu olmadı vatan borcumu ödemiş oldum askerliğin bir Türk erkeği için zorluğu olamaz. Yozgatl bir erkek için hiç olmaz. Böyle bir soru sorman çok saçma.” (İ, 65, Çiftçi).

$\mathrm{Bu}$ anlatıda bize erkeklik ile içselleştirilmiş bir vatan borcu arasında bir ilişki olduğunu gösteriyor.

"Askere normal yaşıtlarımdan biraz geç gittiğim için çok zorlandım ve orada şunu çok iyi anllyor insan. Ne dersen? Aile. Onların kıymetini çok iyi anliyorsun. Seni sabahları öperek kaldırmaya kıyamayan annen yerine bağırılarak komutanlar tarafindan uyandırılmak çok acı bir durum." (O, 65, Emekli Öğretmen).

$\mathrm{Bu}$ anlatı da görüldüğü gibi erkeklik ile iktidar olma arasında bir ilişki vardır. Emir komuta zinciri içerisinde erkekler diğer erkeklerin erkine tabi olmak zorunda kalıyorlar. Bu anlamda ac1-ağlamama ve erkek olma arasındaki bağa paralel, başka erkeklerin erki altında çekilen zorlukların erkekleri olgunlaştırdığı düşünülüyor.

Askerliğin erkeğin hayatındaki öneminin büyüklüğü ve yeri, sorulardan alınan cevaplarda da açıkça görülür. Toplumda da önemli yeri olan askerlik sürecini tamamlamayan erkeğin karşısına başka bir zorluk daha çıkar. Türkiye'de çoğunlukla "Askerlik yapmayan erkeğe kız verilmez" ve toplumdan dışlanır. Bunun için askere gitmeyen erkeğe neden kız verilmez sorusu sorulmuştur.

"Ben Türk'üm diyen her erkeğin askerlikyapması şarttır. Sorumluluğu, disiplini ve silah eğitimini ögretir.” (Ü, 21, Öğrenci).

"Şimdi yeğenim, ben sana bu durumu açıklayayım. Askere gitmeyen erkeğin bir hastalı̆̆ var demektir. Yani benim dönemimde öyleydi bu yüzden askere gitmeyen yarım erkektir, kız verilmemesi normal bir şey. Yozgatlı bir erkeğin kendiden bu şekilde bahsedilemsi utanç vericidir." (Ç, 48, Çiftçi).

"Bak aslanım askerlik bir vatan borcudur ve vatan borcunu ödememiş erkekten ne karısina ne de çocuklarına hayır gelir. Biz Yozgatlılar buna çok önem veririz. Vatan bizim için her şeyden önce gelir. Bu yüzden askere gitmeyen erkek ne Yozgatludır ne de erkektir. Kiz verilmemesi en doğrusudur." (A, 48, Kuaför).

Sünnet gibi askerlik de bir erkeklik ritüeli olarak Türkiye'de önemlidir. Askerlik Türk toplumu açısından çok yüce bir kurum kuruluş olarak görülür. Eğlenceler yapılarak askere uğurlanır erkek ama erkeğin içinde yaşadığı zorlukları, düşünceleri kimse önemsemez, Ancak gözden kaçan bu durum, erkeğin üzerinde toplumsal açıdan ağır bir yük oluşturabilir.

\subsection{Para Kazanmak Zorunda Olan (Baba) Erkek}

Türk toplum yapısı ataerkil bir yapıya sahiptir. Bu toplum yapısı içerisinde erkek ön plana alınırken kadın geri plana itilmektedir. Bu yapıda ailenin mutlak reisi erkektir ve maddi geçim yükü onun üzerinde olmalıdır anlayışı hâkimdir. Evin geçimini sağlama görevi erkek üzerine verilmiştir. Bu sanıldığı kadar kolay bir unsur olmamıştır. Evde tek kişinin çalışması ve ataerkil yapı içerisinde bu görevin erkeklere verilmesi onlar için büyük bir sorumluluk gerektiren bir unsur haline gelmiştir. Erkek, erkek olarak var olabilmek ve ataerkil yapı içerisinde saygınlığını koruyabilmek için çalışmak zorunda kalmıştır. Bu nedenle erkek manevi yönlerle ilgilenmekten daha çok "eve ekmek getiren" bir unsur haline getirilmiş maddi boyut olarak görülmeye başlanmıştır. Teknolojik yapının ilerlemesi ile birlikte kol gücüne duyulan ihtiyaç azalmaya, işsizlik oranı artmaya başlamıştır. Bu yönüyle erkekler psikolojik olarak baskı hissetmeye başlamışlardır. Bu nedenle eril tahakkümün ve eril iktidarın sonuçlarından biri olarak erkeğe iş sahibi olma sorumluluğu yüklenmiştir. Yozgat ilinde erkeklere sorulan sorularda ise birbirine benzer nitelikte cevaplar alınmıştır. 
"Geçim sağlamak en büyük derdimiz. Kız olsan, baban seni atmaz, en fazla kocaya verir ama erkekler için öyle mi? Baltaya sap olmalısin, yoksa herkes tepene biniyor.” (X, 25, Üniversite öğrencisi).

"Erkek adam, karısına kızına bakmalı. Daha doğrusu bakacak parası olmalı. Bu mezuniyete yaklaşırken tüm erkeklerin omuzunda.” (H, 23, Üniversite öğrencisi).

"Yozgatta erkek dedin mi bir askerliğini yapmış olacak, iki evini eri olacak. Ne yaparsa yapsın evini geçindirmeyi bilecek." (U, 49, İnşaat Ustasi).

"Adam dediğin evini bilir, evine ekmek getirmeyi bilir. Taşını sıkar suyunu çıkarır, evini geçindirir.” (C, 49, Esnaf).

Yozgat genelinde yapılan araştırmada da edinilen sonuçlarda erkeklerin güzel bir hayat kurmak ve ailelerini geçindirmek için para kazanmak zorunda olduklarını hissettikleri sonucuna varılmıştır. Erkeklerin bahsi geçen bu aşamalara tabi tutulmasının sebebi erkekliklerini ispat etmek zorunda olmalarıdır. Yukarıdaki alıntılar da bize gösteriyor ki genç erkeklerde "evi geçindirme kaygısı" gelecekleri ile ilgili en çok dile getirdikleri sorundur. Türkiye'de yaşanan (Yozgat'ta bilinen bir intihar yok) "baba intiharları" ve erkeklerin ailelerini öldürmeleri yaşanan bu geçinme kaygısının sonuçlarındandır.

\subsection{Evlilik Yolunda Erkek}

Evlilik kurumunun çerçevesi, toplumdan topluma ve toplumun kendi içerisinde değişmektedir. $\mathrm{Bu}$ farklılıklar içerisinde kadın ve erkeğe yüklenen sorumluluklar da farklı olmuştur. Ataerkil toplum yapısı içerisinde erkek, evin maddi boyutuyla ilgilenen bir role sahip olmuştur. Bununla ilgili olarak Türk toplum yapısı içerisindeki erkeklerin evliliğge bakışları birbirlerinden farklı olmuştur.

"Evlenmeden önce düzensiz bir yaşamım vardı. Evlendikten sonra hazır bir yemeğim ve bütün ihtiyaçlarımı karşıladım. Benim için evlilik eşim tarafından bütün ihtiyaçlarımın karşılanmasını ifade etmektedir." (D, 54, Çiftçi).

"Daha sabit bir hayat yaşamak için evlendim. Bunun için evlilik yaptım." (Ç, 48, Çiftçi).

"Benim için evlilik bir hobiyi ifade etmektedir. Hiçbir anlamı yoktur. Futbol oynamak gibi ailem tarafindan zorunlu tutulduğum için evlendim. Bunun haricinde bir imkânım olsaydı evlenmezdim." (Z, 60, Esnaf).

"Çocuk sahibi olabilmek için evlendim. Çocuklarım olsun ve düzenli bir hayata sahip olmak istiyordum. Bu yüzden evliliği tercih ettim. Benim için evlilik çoğalmak ve soyunu devam ettirmeyi ifade ediyor.” (N, 62, İmam).

"Sirf çocuk sahibi olmak için evlendim. Evlilik benim için çocuk sahibi olmayı ifade etmektedir. Çocuk sahibi olmak dışında evliliğin hiçbir artısı bulunmamaktadır.” (U, 49, İnşaat Ustası).

Sancar'a (2009, ss.63-64) göre “evlilik, emeğinden başka satacak bir şeyleri olmayan mülksüz bir erkeğe bile üzerinde otorite sahibi olarak, bir ailenin geçimini sağlama yoluyla saygın bir statü verir. Ücretli iş sahipliği, erkeği hükmedeceği bir eş ve çocuk sağlayarak onu güç sahibi yapar." Yozgat ili ataerkil yapısını hala barındıran bir yapıya sahiptir. Bunun için evlilik için her erkeğin vermiş olduğu cevap farklı olmuştur. Kimisi için evlilik cinsel bir birliktelik anlamını ifade ediyor olsa da kimisi için de çocuk sahibi olmak için evlilik kurma amacı güdülmüştür. Evlendikten sonra erkeklerin evliliğe bakış açıları değişme yaşanmaya başlamıştır. Bununla birlikte erkekler için evlendikten sonra evlilik sürecinde ne gibi değişimler yaşandığı ölçülmeye çalışılmıştır. 
"Evlilik ile birlikte sosyal hayatım kisıtlanmaya başladı. Bununla birlikte geçim derdim iki katına çıkmaya başladı. Önceden tek kendimi düşünüyordum. Şimdi düşünmem gereken kendimden hariç bir eşim ve çocuğum var." (V, 59, Nalbur).

"Bekârken çok rahat bir hayatım vardl. Evlendikten sonra çok erken çocuk sahibi oldum. Ĕger çocuğum olmasaydı evliliğimi devam ettirmezdim. Evliliğim çocuğum sayesinde devam ediyor fakat ne olursa olsun eşime bakmakla yükümlüyüm. Evlilik içerisinde dışarlya kendini doğru ifade etmek için ne olursa olsun her şeyi yutup içine atmak zorundasın." (Y, 54, Çiftçi).

"Evlilik ile ilgili beklentilerim çok farklıydı. Hayatımı düzene koyan birisi olarak hayatıma devam edeceğimi düşünüyordum fakat evlendiğim günden beri alkol kullaniyorum. Hayat daha yorucu ve zor hale gelmeye başladl." (P, 65, Çiftçi).

Anlatılardan da görüldüğü gibi bir erkeğin evlilikten -kadınlardan- beklediği, toplumsal cinsiyete dayalı iş bölümünde kadına biçilen "anne, eş" rollerine uygun olarak evlilik içinde kendisine bakılması. Öte yandan, geleneksel toplumlarda evliliğin nedenlerine konusunda yapılan araştırmalar Yozgat için de geçerlidir: cinsel ihtiyaçlar ve üreme yolu ile özel mülkiyet ve sermaye üzerinde erkeğin kontrolünün sağlanması. Ancak daha önce yapılan çalışmalardan farklı olarak erkekler evliliği statü olarak görmek yerine özgürlüklerini kısıtlayan bir kurum olarak algılamaktadırlar. Yukarıdaki alıntılar, Yozgat'ta yaşanan bir vaka olmamasına rağmen, son dönem Türkiye'de yaşanan "baba intiharları" ve birlikte ailelerini öldürme eylemlerinin altında yatabilecek sebeplere örnek gösterilebilir. Evliliğin bir erkek üzerinde kurduğu ifade edilen bu sosyo-psikolojik baskı aslında Türkiye'de "erkek olmak" algısının sonucudur diyebiliriz. "Erkek adam ağlamaz" ile başlayan ve daha sonra "erkek evin direğidir" algısı ile pekiştirilen bu durum cinsiyeti erkek olan insanları bir kıskaca sokmakta ve pek çok toplumsal sorunun da kaynağı olmaktadır.

\section{SONUÇ}

Toplumda toplumsal cinsiyete dayalı iş bölümü sonucu erkeğin ve kadının belirli rolleri tanımlanmıştır. Erkeğin ve kadının yaşamları boyunca toplum tarafindan belirlenen bu rollere ayak uydurması beklenir. Erkeğin ve kadının cinsiyet rollerine göre davranan bireyler toplum tarafindan kabul edilirken, uygun davranış sergilemeyenler ise toplum tarafından reddedilmişlerdir. Ataerkil rejimin yarattığı erkeklik algısında toplum içinde, erkekten, kabul edilen erkeklik kodlarını sergilemesi beklenir. Erkek toplum tarafindan beklenenleri yerine getirdiği zaman erkeklik hiyerarşisinde üst katmanlarda görülmüş ve toplum tarafından değer verilen bir unsur olmuştur fakat erkek ataerkil rejim tarafından tanımlanan erkelik rollerini yerine getirmediği zaman toplum içinde dışlanma yaptırımı ile karşılaşmıştır.

Türkiye toplumunda erkeğin de kadının da rollerinin belirlenmesinde ataerkil yapının etkisi vardır. Ataerkil yapının etkisi, erkeğin cinsiyet rollerinde egemen olmasında etkin rol oynamıştır. Günümüzde cinsiyet rolleri modernleşme süreçleri ile değişim göstermiş olsa da Türkiye'nin toplum yapısında günümüzde dahi geleneksel yapının etkileri görülür. Erkeğin çalışıp ailesini geçindirmek zorunda olduğunu, kadının ise ev içi ile kısıtlandırıldığı gerçeğini çok az değişime uğramıştır. Ataerkil yapı erkek egemenliği olarak görülse de erkekleri olumsuz olarak etkilediği noktalar da vardır. Ataerkil yapının erkeklere dayattığı birtakım sorumluluklar vardır. Bunlar daha küçük yaştaki bir çocuğa erkek olmak için neler yapılması gerektiğini söyler. Yetişkin erkekler için ise çalışıp bir aile kurup ve ailenin geçimini sağlaması üzerine beklentiler kurar. Ataerkil yapı erkeğe toplumda var olabilmek için sürekli bir takım sorumluluk yükler. Erkeğin toplumda var olma çabası onu hayatı boyunca bir erkeklğini ispatlama mücadelesi içine sokar.

Türkiye'nin toplum yapısında erkeklerin cinsiyet rejimi içinde saygınlık kazanabilmek için belirli süreçlerden geçmesi gerekir. Bunlar; sünnet olmak, askere gitmek, iş bulup çalışmak ve erkeklik aşamasının son kademesi olan evlenip aile kurmaktır. Geleneksel toplum yapısında bu süreçleri yerine getirmeyen erkek toplum tarafından dışlanır. Bu süreçler erkeğin hayatında önemli yere sahiptir. Erkeklik aşamasının başı olan sünnet olgusu, oğlan çocuğu üzerinde önemli etkiye sahiptir. Sünnet olmak daha küçük yaştaki 
çocuğa erkek olmayı aşılar. Geleneksel toplum yapısında askerliğin yeri veri önemi çok büyüktür. Bir sonraki aşama olan iş bulup çalışma ise erkekliğin inşa sürecinde önemli yere ve etkiye sahiptir. Erkekliğin bir diğer aşaması olan evlilik süreci erkekliğini bambaşka bir evreye taşıyarak toplum tarafından belirlenen erkeklik süreçlerini tamamlamıştır. Bir aile yapısının içine giren erkek burada baba olduktan sonra hayatı boyunca yaşadığı ataerkil yapının getirdiği kadın ve erkek algısını bu sefer kendi çocukları üzerinden devam ettirir. Ataerkil yapının kendi üzerinde ki bütün zorlukları bu sefer kendi çocuklarına yaşatır.

Yozgat'taki erkeklik algısı incelendiğinde Türkiye'deki hegemonik erkeklik anlayışından beslenen bir erkeklik olduğu görülmüştür. Erkekliğin ispatı gibi görülen sünnet, askerlik, evlilik ve iş bulma aşmalarının Yozgat'taki erkeklerin hayatları için de önemli olduğu. Ancak askerlik aşamasının ülkücü değerlere bağl1lı̆̆ ile bilinen bir şehirde yaşayan erkekler için daha fazla anlamı olduğu görülmüştür. Öte yandan, evlilik çocuk ve cinsellik için zorunlu bir işlem olarak görülürken, evliliği erkeklerin özgürlüklerini kısıtlayan bir kurum olarak yorumlamışlardır. Bu çalışma bize Yozgat'a ait "Yozgat erkekliği" şeklinde ayrı tanımlanabilecek bir erkeklik kategorisine raslanılmadığını ancak Yozgat’ta erkeklik algısına şehrin sosyo-kültürel dokusunun etki ettiğini göstermiştir.

\section{KAYNAKLAR}

Atay, T. (2004). Erkeklik En Çok Erkeği Ezer. Toplum ve Bilim,101.

Aylin, N. (2015). Kadın Bedeni ve Toplumsal İzdüşümleri: Sosyolojik Bir Bakış. Fatma Zehra Fidan ve Duygu Alptekin (Ed.), Kadın Bedeni ve İstismarı içinde. Opsiyon Yayınları.

Barutçu A. (2015), "Ucundan Azıcık”la Atılan Sağlam Temel: Türkiye'de Sünnet Ritüeli ve Erkeklik İlişkisi. A Journal of Identity and Culture, 3, 129-155.

Barutçu, A. (2013). Türkiye'de erkeklik inşasının bedensel ve toplumsal aşamaları (Yayımlanmamış doktora tezi). Ankara Üniversitesi Sosyal Bilimler Enstitüsü Kadın Çalışmaları Anabilim Dalı.

Bem: L. (1985). An drogyny and Gender Scheme Theory: A Conceptual and Empirical Integration. Solderegger, T.B. (ed.), Psychology and Gender Nebraska Symposium on Motivation. Lincoln ve London: University of Nebraska Press.

Beşpınar, F. U. (2014). Toplumsal Cinsiyet ve Aile. Türkiye Aile Yapısı Araştırması, Tespitler, Öneriler içinde. Aile ve Sosyal Politikalar Bakanlığı Aile ve Toplum Hizmetleri Genel Müdürlüğ̈̈, Araştırma ve Sosyal Politika Serisi 07, 1.Basım, Çizge Tanıtım ve Kırtasiye Ltd. Şti, 110-169.

Bird: R. (1996). Welcome To The Men's Club: Homosociality and The Maintenance Of Hegemonic Masculinity. Gender \& Society, 10(2), 120-132.

Bora, A. (2012). Toplumsal Cinsiyete Dayalı Ayrımcılık. Kenan Çayır ve Müge Ayan Ceyhan (der.), Ayrımcılık Çok Boyutlu Yaklaşımlar içinde. İstanbul Bilgi Üniversitesi Yayınları, İstanbul, 175-187.

Bozok, M. (2013). Eleştiren İle Eleştirilenler Arasında Nazik Karşılaşmalar: (Pro) Feminist Bir Yaklaşımla Trabzon'da Erkeklikleri İncelemek. Fe Dergi, 6(1), 79.

Budd, J. W. (2011). The Thought of Work. Cornell UniversityPress.

Cengiz, K., U.U., Tol, \& Küçükural, Ö. (2004). Hegemonik Erkekliğin Peşinden. Toplum ve Bilim, 10, 50-70.

Connell, R. W. (1995, 2005). Masculinities. University of California Press.

Connell, R. W. (2000). The Men And The Boys. University of California.

Connell, R. W., \& Messerschmidt, J. W. (2005). Hegemonic Masculinity: Rethinking The Concept. Gender \& Society, 19(6), 829-859.

Çakır, H. (2017), Erkeklerin Sosyalleşmesinde Öğrenilmiş Güçlülük: Kavramsal Bir İnceleme. Researher: Social Sciences Studies, Cilt 5, Say1 IV: 320-334.

Çelik, G. (2016). Erkekler (De) Ağlar!: Toplumsal Cinsiyet Rolleri Bağlamında Erkeklik İnşası ve Şiddet Döngüsü. Fe Dergi, 8(2), 1-12.

Demren, Ç. (2003). Erkeklik, Ataerkillik ve İktidar İlişkileri. Hacettepe Üniversitesi Kadın Sorunları Araştırma ve Uygulama Merkezi, http://www.huksam.hacettepe.edu. tr/erkek. htm.

Ecevit, Y. \& Karkıner, N. (2011). Toplumsal Cinsiyet Sosyolojisi. Eskişehir: Anadolu Üniversitesi Yayınları. 
Flood, M. (2008). Men, Sex, And Homosociality: How Bonds Between Men Shape Their Sexual Relations With Women. Men And Masculinities, 10(3), 339-359.

Gedik, E. (2016). Bir Tüketim Kültürü Ürünü Olarak Anti-Kahraman Erkek İmajları. ViraVerita E-Dergi, (4), 37-58.

Gedik, E. (2018). Homososyal Birliktelik Örneği Olarak Mahalleyi Korumak: Sifır Bir Dizisinde Erkeklik Halleri. Fe Dergi 10(2), 60-70.

Güldü, A. ve Kart E. (2009), Toplumsal Cinsiyet Rolleri ve Siyasal Tutumlar: Sosyal Psikolojik Bir Değerlendirme. Ankara Üniversitesi SBF Dergisi.

Hacısoftaoğlu, İ. \& Bulgu, N. (2015). “Yedi dağın ötesindeki çocuklar: Güreşte erkeklik ve şiddet.” Betül Yarar (der.) Şiddetin Cinsiyetli Yüzleri içinde. İstanbul: Bilgi Üniversitesi Yayınları.

Kimmel, M. S., Hearn, J., \& Connell, R. W. (Eds.). (2004). Handbook Of Studies On Men And Masculinities. Sage Publications.

MacInnes, J. (1998). End Of Masculinity: The Confusion Of Sexual Genesis And Sexual Difference In Modern Society. McGraw-Hill Education (UK).

Oakley, A. (2015). Sex, Gender And Society. Ashgate Publishing, Ltd..

Odabaş: (2013). İnternette Erkeklik, Cinsel Sağlık Politikası ve Ticareti. Doğu Batı Dergisi, 63, $203-221$.

Onur, H. ve Koyuncu, B. (2004). 'Hegemonik' Erkekliğin Görünmeyen Yüzü: Sosyalizasyon Sürecinde Erkeklik Oluşumları ve Krizleri Üzerine Düşünceler. Toplum ve Bilim, 101, 31-49.

Oran Kalkınma Ajansı Yozgat Sosyal Durum Analiz, http://www.oran.org.tr/images/dosyalar/2019091815 5744_2.pdf, erişim tarihi, 19.04.2020.

Özgün, C. (2017), Türkiye'nin Askerlik Sisteminin Tarihsel Süreç Bağlamında İncelenmesi. Üsküdar Üniversitesi Sosyal Bilimler Dergisi, 3(4), 51-90.

Öztan, G. (2013), Türkiye'de Milli Kimlik İnşası Sürecinde Militarist Eğilimler ve Tesirleri. NY Sünbüloğlu (der.), Erkek Millet Asker Millet: Türkiye'de Militarizm, Milliyetçilik, Erkek (lik) ler. İstanbul: İletişim.

Öztan, G. (2014), Türkiye'de Militarizm: Zihniyet, Pratik ve Propaganda. İstanbul Bilgi Üniversitesi Yayınları.

Öztürk, A. (2012). Eril Bedenselleşme: Hegemonik Erkek Bedeninin İnşası. Felsefe ve Sosyal Bilimler Dergisi (FLSF), (13).

Sancar, S. (2009), Erkeklik: Imkânsız İktidar Ailede, Piyasada, Sokakta Erkekler. İstanbul: Metis.

Sancar, S. (2014). Türk Modernleşmesinin Cinsiyeti: Erkekler Devlet, Kadınlar Aile Kurar. İletişim Yayınları.

Selek, P. (2011). Sürüne Sürüne Erkek Olmak. İletişim Yayınları.

Sığın, A. \& Canatan, A. (2018). Connell'ın “Erkeklikler” Teorisinde İşbirlikçi Erkek, Madun Erkek Ve Marjinal Erkek: Hegemonik Erkekliğin Kavramsal Hegemonyası. Sosyal Bilimler Dergisi, 5(32).

Taşıtman A. (2013). Terbiye Edilen Bedenler, Tecrübe Edilen Erkeklik: Sünnet Ritüeli (Yayımlanmamış yüksek lisans tezi). Ankara Üniversitesi, Kadın Çalışmaları.

Top, F. Esüntimur, Y. Uykan, L. \& Pekdemir, E. (2008). Giresun İlindeki Ailelerin Sünnet Konusundaki Bilgi Tutum ve Davranışları. Çocuk Dergisi.

Topuz, S. K. \& Erkanlı H. (2016). Toplumsal Cinsiyet Bağlamında Kadın ve Erkeğe Atfedilen Anlamların Metafor Yöntemiyle Analizi. Alternatif Politika, 8(2), 300-321.

Türkoğlu, B. (2013). Fay Hattında Erkeklikler: Çalışma ve İşsizlik Ekseninde Erkekliğe Bakış/Manhood on the Fault Line: Examining Manhood under the Frame of Working and Unemployment. Mülkiye Dergisi, 37(4), 33-61.

Yavuz, M., Demir T. ve Doğangün B. (2012). Sünnetin Çocuk Ruh Sağlığı Üzerine Etkisi: Gözden Geçirme Çalışması. Türk Psikiyatri Dergisi, 23(1), 63-70.

Yavuz, Ş. (2014), İktidar Olma Sürecinde Erkeklerin Erkeklikle İmtihanı. Milli Folklor, 26(104).

Yozgat Nüfusu, https://www.nufusu.com/il/yozgat-nufusu, erişim tarihi, 19.04.2020. 